\section{OPEN}

SUBJECT AREAS: APPLIED MICROBIOLOGY

FUNGAL BIOLOGY

Received

8 January 2015

Accepted

11 March 2015

Published

12 May 2015

Correspondence and requests for materials should be addressed to S.D.S. (shamala@um. edu.myl

\title{
Activity of Novel Synthetic Peptides against Candida albicans
}

\author{
Kah Yean Lum', Sun Tee Tay', Cheng Foh Le' ${ }^{2}$, Vannajan Sanghiran Lee ${ }^{3}$, Nadia Hanim Sabri ${ }^{3}$, \\ Rukumani Devi Velayuthan', Hamimah Hassan' \& Shamala Devi Sekaran'
}

\begin{abstract}
'Department of Medical Microbiology, Faculty of Medicine, University of Malaya, Kuala Lumpur, Malaysia, ${ }^{2}$ School of Pharmacy, Faculty of Science, University Nottingham Malaysia Campus, Semenyih, Selangor, Malaysia, ${ }^{3}$ Department of Chemistry, Faculty of Science, University of Malaya, Kuala Lumpur.
\end{abstract}

Candida spp. are the most common causes of fungal infections worldwide. Among the Candida species, Candida albicans remains the predominant species that causes invasive candidiasis in most countries. In this study, we used two peptides, KABT-AMP and uperin 3.6 as templates to develop novel antifungal peptides. Their anticandidal activity was assessed using a combination of MIC, time-killing assay and biofilm reduction assay. Hybrid peptides, KU2 and KU3 containing a mixed backbone of KABT-AMP and Uperin 3.6 demonstrated the most potent anticandidal activity with MIC values ranging from $8-16 \mathrm{mg} / \mathrm{L}$. The number of Trp residues and the amphipathic structure of peptides probably enhanced the anticandidal activity of peptides. Increasing the cationicity of the uperin 3.6 analogues resulted in reduced MIC from the range of 64-128 mg/L to $16-64 \mathrm{mg} / \mathrm{L}$ and this was also correlated with the antibiofilm activity and killing kinetics of the peptides. Peptides showed synergistic effects when used in combination with conventional antifungals. Peptides demonstrated low haemolytic activity but significant toxicity on two normal human epithelial cell lines. This study provides us with a better understanding on the structure-activity relationship and the balance between cationicity and hydrophobicity of the peptides although the therapeutic application of the peptides is limited.

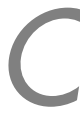

andida spp. are human commensal microbes that commonly reside on skin, gastrointestinal tract, genitouninary system, oropharynx and upper respiratory tract without causing harm to healthy individuals ${ }^{1}$. However, when the host immune and defense system are debilitated, it becomes pathogenic and causes several types of infection, ranging from superficial infection, such as vulvovaginal candidiasis, esophageal or oropharyngeal candidiasis, to life-threatening invasive disorders including candidemia as well as disseminated and deep tissue candidiasis ${ }^{1,2}$.

Candida spp. are the most common causes of fungal infections worldwide. According to data reported by National Healthcare Safety Network (NHSN) at Centers of Diseases Control and Prevention (CDC), Candida spp. ranked the fifth among hospital-acquired pathogens ${ }^{3}$. In the United States, Candida spp. were the fourth most common causative pathogens of nosocomial bloodstream infection and associated with high morbidity and mortality rates ${ }^{4}$. Among 15 pathogenic Candida isolates, Candida albicans remains as the predominant species that causes invasive candidiasis in most countries. However, recent surveillance studies have demonstrated an increasing incidence of candidemia due to non-albicans species such as C. glabrata, C. parapsilosis, C. tropicalis, and C. krusei $^{4-8}$.

The risk factors for invasive candidiasis include immune disorders, exposure to broad-spectrum antimicrobial agents, use of immunosuppressive drugs, solid organ or bone marrow transplantation, malignancies, parenteral alimentation and indwelling catheters ${ }^{1,9}$. Besides that, studies showed that critically ill patients in ICU with prolonged stay of more than 7 days are predisposed to candidemia and candiduria ${ }^{5,10}$.

Global report on antimicrobial resistance surveillance published by WHO documented that only three classes of conventional antifungal drugs are currently being used to treat invasive candidiasis; they include the azoles (i.e. fluconazole), the echinocandins (i.e. caspofungin) and the polyenes (i.e. amphotericin B) ${ }^{11}$. In recent years, antifungal resistances in Candida spp., especially in non-albicans species, have been observed. For example, $C$. krusei had reduced susceptibility to fluconazole and C. glabrata was resistant to both azoles and echinocandins ${ }^{12}$. The emergence of antifungal resistant pathogens has been of great concern and prompted the development of alternative antifungal agents.

Antimicrobial peptides (AMPs) are relatively small (generally 10 to 50 amino acids), cationic ( +2 to +9 ), containing $\geq 30 \%$ hydrophobic residues and amphipathic (hydrophobic and hydrophilic amino acids on opposite 
faces) molecules which have been found in most living organisms ranging from bacteria to plants, invertebrate and vertebrate spe$\operatorname{cies}^{13,14}$. They act as the first line of defense and encompass direct antimicrobial activity against a broad spectrum of invading pathogens including bacteria, fungi, viruses and protozoa by using different modes of action as described previously ${ }^{15,16}$. Thus, AMPs can be potentially promising candidates for development of novel therapeutic agents against pathogens.

Several approaches such as template-based design, biophysical modelling, and computer-aided design have been proposed to design synthetic $\mathrm{AMPs}^{17}$. Template-based strategy is known as de novo design of peptide analogues based on natural AMPs with known antimicrobial activity. This approach is often more convenient and has been extensively applied by researchers to elucidate the structureactivity relationship of peptides and further enhance the antimicrobial potency of natural AMPs with low toxicity to mammalian cells ${ }^{18,19}$. In our study, KABT-AMP, a synthetic peptide ${ }^{20}$ and uperin 3.6, a naturally occurring peptide ${ }^{21}$ with known activity were selected and modified in an attempt to improve their antifungal activity. Physicochemical properties including size, residue composition, overall charge, hydrophobicity, and amphipathic structure were taken into consideration while designing synthetic AMPs.

\section{Results}

Peptide design. KABT-AMP and uperin 3.6 peptides were selected as templates for designing synthetic AMPs. Uperin 3.6 adopts a welldefined amphipathic $\alpha$-helix, with hydrophobic side above and hydrophilic side below the polypeptide backbone. Synthetic modification performed by Chia et al had revealed that three lysine residues in the sequence of uperin 3.6 are crucial for antimicrobial activity $^{21}$. To further enhance the antimicrobial activity of uperin 3.6, three lysine-substituted analogues of uperin 3.6 (Upn-lys4, Upn-lys5, and Upn-lys6) were designed by replacing less hydrophobic amino acids with cationic lysine residues so that activity variation depends solely on altering the charge. The overall charge of a parent peptide was increased to $+4,+5$ and +6 respectively without disrupting the amphipathic structure of the peptide. In addition, four hybrid peptides (KU1, KU2, KU3, and KU4) were designed by selecting and fusing peptide fragments from KABT-AMP and uperin 3.6. KU1 was designed by truncating the first nine residues at the $\mathrm{N}$-terminus of KABT-AMP which was then fused to the $9^{\text {th }}$ to $17^{\text {th }}$ C-terminus of residual fragment (VVNVLKNLF-NH $\mathrm{N}_{2}$ ) of uperin 3.6. Likewise, KU2, KU3 and KU4 were also designed using the same approach by truncating first eleven, twelve and thirteen residues at $\mathrm{N}$-terminus of KABT-AMP, respectively, and fused with the respective $11^{\text {th }}$ to $17^{\text {th }}, 12^{\text {th }}$ to $17^{\text {th }}$ and $13^{\text {th }}$ to $17^{\text {th }} \mathrm{C}$-terminus residues fragment of uperin 3.6 with amidation. The sequence and physicochemical properties of all designed peptides are provided in Table 1. The amphipathic orientation of the residues in helical structure of four hybrid peptides are displayed using the helical wheel projection (Figure 1).

Anticandidal activity of designed peptides. The MIC of the reference and designed peptides against C. albicans, C. krusei and C. parapsilosis were determined as shown in Table 2. Conventional antifungal agents such as fluconazole and amphotericin B were included in this study as controls. Among the hybrid peptides, KU2 and KU3 demonstrated the most potent antifungal activity, showing MIC values ranging from 8 to $16 \mathrm{mg} / \mathrm{L}$ against four Candida strains. KU1 and KU4 also displayed good activity, with MIC values ranging from 16 to $32 \mathrm{mg} / \mathrm{L}$ and 16 to $64 \mathrm{mg} / \mathrm{L}$ respectively. All four KU hybrid peptides showed improved anticandidal activity when compared to their parent peptides KABT-AMP (MIC of 32 to $64 \mathrm{mg} / \mathrm{L}$ ) and uperin 3.6 (MIC of 64 to $128 \mathrm{mg} / \mathrm{L})$.
In terms of uperin 3.6 analogues, substitution of a single Lysine residue into the parent peptide (Upn-lys4) did not improve the antifungal activity against $C$. albicans strains and C. krusei. Upn-lys5 and Upn-lys6 displayed two-fold reduction in MIC values against $C$. albicans and C. krusei (MIC of 32 to $64 \mathrm{mg} / \mathrm{L}$ ) suggesting that replacement of two lysine residues was required to improve the antimicrobial activity of the parent peptide by two-fold. With the exception of C. parapsilosis, the antimicrobial activity of uperin 3.6 was improved by twofold as the number of lysine residue substituted into template peptide increased. As for the standard antifungal drugs, amphotericin $\mathrm{B}$ has the most potent antimicrobial activity with MIC values ranging from 0.5 to $1 \mathrm{mg} / \mathrm{L}$ against $C$. albicans and non-albicans species. For fluconazole, two C. albicans strains and C. parapsilosis showed MIC values ranging from 1 to $2 \mathrm{mg} / \mathrm{L}$ while C. krusei, a species that is intrinsically resistant to fluconazole, demonstrated MIC value of $64 \mathrm{mg} / \mathrm{L}$.

Killing kinetics of designed peptides. Antifungal activity of the designed peptides was further assessed by determining their killing kinetics on C. albicans SC5314 strain at concentrations of $2 \times$ the respective MICs. Among the hybrid peptides, KU4 killed the yeast cells effectively, achieving a mean maximum log decrease of $5.55 \pm$ $0.08 \mathrm{CFU} / \mathrm{mL}$ ( $>99.99 \%$ killing) within 6 hours of test period. KU1, KU2 and KU3 decreased the number of viable fungal cells with mean $\log$ reduction of $2.95 \pm 0.59 \mathrm{CFU} / \mathrm{mL}$ (99.82\% killing), $2.77 \pm$ $0.54 \mathrm{CFU} / \mathrm{mL}(99.73 \%$ killing) and $3.28 \pm 0.30 \mathrm{CFU} / \mathrm{mL}(99.94 \%$ killing), respectively, within 6 hours (Figure 2A). However, the parent peptide KABT-AMP caused $5.4 \pm 0.09$ log decreases in $\mathrm{CFU} / \mathrm{mL}$ ( $>99.99 \%$ killing) within 4 hours, obtaining a better killing kinetics compared with the hybrid peptides (Figure 2C). In terms of uperin 3.6 analogues, Upn-Lys 6 and the parent peptide uperin 3.6 killed the yeast cells rapidly within 4 hours test period, exhibiting a mean maximum log reduction of $5.56 \pm 0.07 \mathrm{CFU} / \mathrm{mL}$ (>99.99\% killing) and $5.54 \pm 0.13 \mathrm{CFU} / \mathrm{mL}$ (>99.99\% killing), respectively. Upn-Lys 4 and Upn-Lys 5 attained respective log decrease of $4.12 \pm 1.36 \mathrm{CFU} / \mathrm{mL}$ (99.97\% killing) and $4.95 \pm$ $1.24 \mathrm{CFU} / \mathrm{mL}$ (99.99\% killing) within 6 hours (Figure 2B). With regard to the antifungal drugs, amphotericin $\mathrm{B}$ demonstrated the best killing kinetics, by eradicating the fungal cells rapidly within 2 hours with $5.44 \pm 0.07 \log$ reduction ( $>99.99 \%$ killing) in CFU/ $\mathrm{mL}$ (Figure 2C). Fluconazole displayed a slight reduction in yeast growth ( $<99.9 \%$ reduction), showing fungistatic activity against the tested strain (Figure 2C).

Biofilm reduction assay. Biofilms formation is often associated with antifungal resistance as compared to planktonic cells and requires drug concentrations of 30-2000 times the corresponding MIC values to reduce $50 \%$ of the biofilms metabolic activity ${ }^{22}$. The susceptibility of the fungal biofilms to the designed peptides was assessed by using XTT reduction assay, which enables quantitation of the number of living cells in 24 hour-old biofilms after treatment. Based on the results shown in Figure 3, the biofilm metabolic activity of which Candida decreased as the concentration of peptides increased from $1 \times$ to $4 \times$ the planktonic MIC. KU4 with a BEC- 2 value of $96 \mathrm{mg} / \mathrm{L}$ demonstrated the highest ability to eradicate biofilms among the hybrid peptides. The BEC-2 value for uperin 3.6 was $192 \mathrm{mg} / \mathrm{L}$ while its analogues, upn-lys4, upn-lys5 and upn-lys6 showed BEC2 values of $192 \mathrm{mg} / \mathrm{L}, 128 \mathrm{mg} / \mathrm{L}$ and $96 \mathrm{mg} / \mathrm{L}$, respectively. The parent peptide KABT-AMP exhibited good antibiofilm activity with a BEC-2 value of $64 \mathrm{mg} / \mathrm{L}$. In contrast, the conventional antifungal agent, amphotericin $\mathrm{B}$, displayed the most potent antibiofilm activity with a BEC- 2 value of $<1 \mathrm{mg} / \mathrm{L}$ while fluconazole had a BEC-2 value of $>4 \mathrm{mg} / \mathrm{L}(>4 \times$ MIC) (Table 3$)$.

Growth inhibitory effect of the peptide-peptide and peptideantifungals combination. The in vitro synergism effects of the peptide-peptide and peptide-antifungals combination were 


\begin{tabular}{|c|c|c|c|c|c|}
\hline \multicolumn{6}{|l|}{ Hybrid Peptides } \\
\hline KU2 & GIWKK $^{5}$ WIKKW ${ }^{10}$ LNVLK $^{15}$ NLF-NH $_{2}$ & 18 & 5 & 55 & -0.122 \\
\hline KU3 & GIWKKK $^{5}$ WIKKW ${ }^{10}$ LKVLK $^{15}$ NLF-NH $_{2}$ & 18 & 6 & 55 & -0.144 \\
\hline KU4 & GIWKKK $^{5}$ WIKKW ${ }^{10}$ LKKLK $^{15}$ NLF-NH $_{2}$ & 18 & 7 & 50 & -0.594 \\
\hline Upn-lys5 & GVIKAAKKVVKVLKNLF-NH ${ }_{2}$ & 17 & 5 & 58 & 0.700 \\
\hline Upn-lys6 & GVIKAAKKVVKVLKKLF-NH ${ }_{2}$ & 17 & 6 & 58 & 0.676 \\
\hline \multicolumn{6}{|l|}{ Reference Peptides } \\
\hline KABT-AMP & $\mathrm{GIWKK}^{5} \mathrm{WIKKW}{ }^{10} \mathrm{LKKLL}^{15} \mathrm{KKLWK}^{20} \mathrm{KG}$ & 22 & 10 & 45 & -0.873 \\
\hline Uperin 3.6 & GVIDA $^{5}$ AKKVV ${ }^{10}$ NVLKN $^{15}$ LF-NH $_{2}$ & 17 & 3 & 52 & 0.747 \\
\hline
\end{tabular}

identified by using a modified checkerboard method. Most of the peptide-peptide combinations showed no synergistic effect against C. albicans SC5314 and ATCC 90028 strains and were in the additive or indifferent range (Supplementary data: Table S1). All the peptideamphotericin B combinations demonstrated synergistic effects with
FIC indices of less than 0.5 when tested against C. albicans SC5314 strain. In contrast, there are only four peptide-fluconazole combinations (KU4, KABT-AMP, Upn-lys6 and uperin 3.6) that displayed synergistic effects against SC5314 strain. However, most of the peptides inhibited the growth of ATCC 90028 strain when (a)

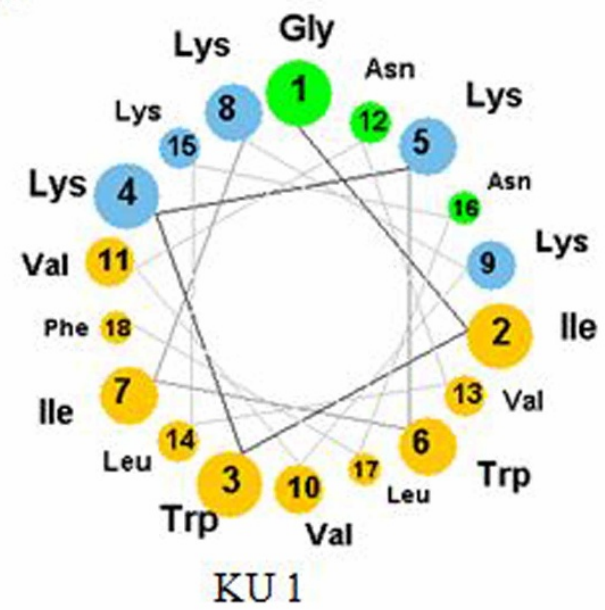

(c)

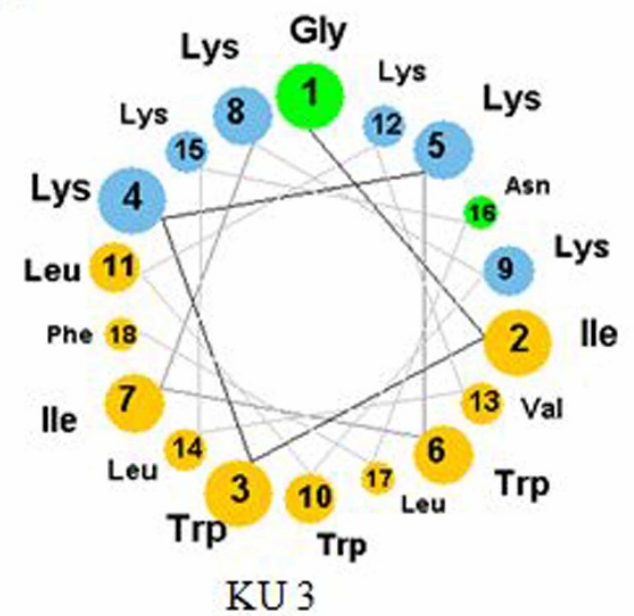

(b)

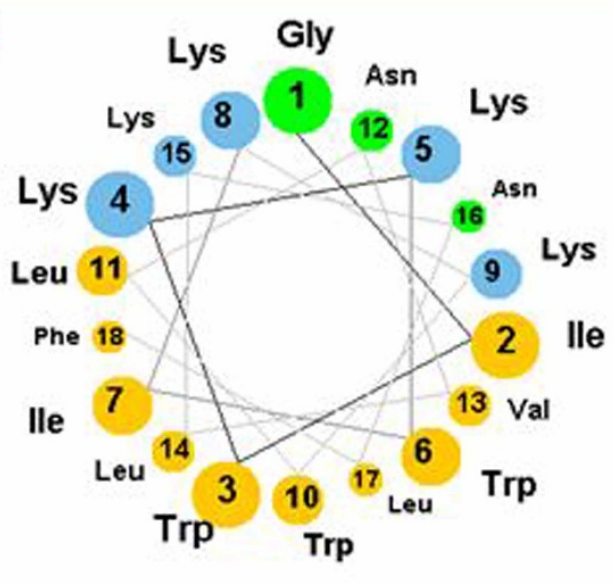

KU 2

(d)

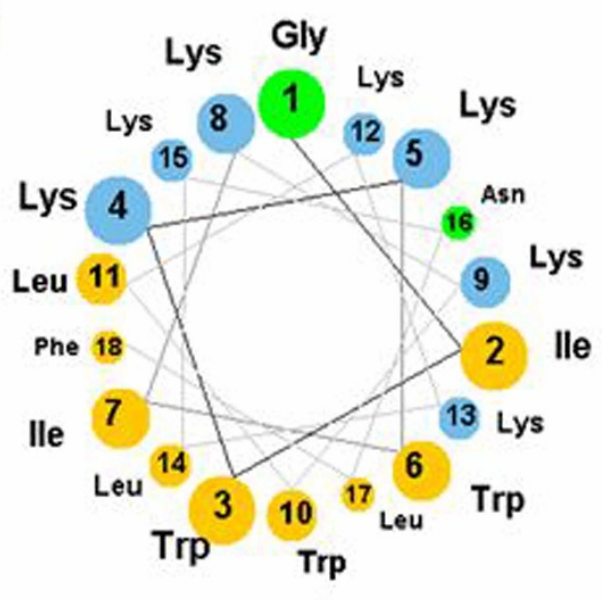

KU 4

Figure $1 \mid$ Helical wheel projections of (a) KU1, (b) KU2, (c) KU3 and (d) KU4. Yellow circles represent hydrophobic residues. Blue and green circles correspond to hydrophilic residues obtained from CAMP (Collection of Anti-Microbial Peptides) http://www.camp.bicnirrh.res.in/. 
Table 2 | Antimicrobial activities (MIC) of peptides and conventional antifungals against Candida strains

Minimum Inhibitory Concentration $(\mathrm{MIC})(\mathrm{mg} / \mathrm{L})$

\begin{tabular}{|c|c|c|c|c|}
\hline Peptide or antifungal & \multicolumn{2}{|c|}{ Candida albicans } & $\frac{\text { Candida krusei }}{\text { ATCC } 6258}$ & $\frac{\text { Candida parapsilosis }}{\text { ATCC } 22019}$ \\
\hline KU1 & 16 & 32 & 32 & 16 \\
\hline KU3 & 8 & 16 & 16 & 8 \\
\hline KU4 & 32 & 64 & 16 & 32 \\
\hline Upn-lys4 & 64 & 128 & 64 & 64 \\
\hline KABT-AMP & 32 & 64 & 64 & 64 \\
\hline Uperin 3.6 & 64 & 128 & 64 & 128 \\
\hline Fluconazole & 1 & 2 & 64 & 1 \\
\hline Amphotericin B & 1 & 0.5 & 1 & 1 \\
\hline
\end{tabular}

tested in combination with amphotericin B except Upn-lys6 and uperin 3.6. In term of fluconazole, KU4 was the only peptide displaying a synergistic effect when used in combination with fluconazole against both strains.

Cytotoxicity of peptides on normal human cells. Haemolytic assay was carried out to determine the ability of the peptides to disrupt the membrane integrity of mammalian cells. The hybrid peptide KU1 showed haemolytic activity $(>10 \%)$ at concentrations lower than the MIC doses. KU2 and KU3 also displayed moderate haemolytic activity with $\mathrm{HC}_{10}$ and $\mathrm{HC}_{50}$ of $7.33 \pm 0.73 \mathrm{mg} / \mathrm{L}$ and $57.71 \pm$ $9.80 \mathrm{mg} / \mathrm{L}$ for KU2 and $5.65 \pm 0.85 \mathrm{mg} / \mathrm{L}$ and $55.20 \pm 11.90 \mathrm{mg} /$ $\mathrm{L}$ for KU3. KU4 was the hybrid peptide with the least haemolytic activity $\left(\mathrm{HC}_{10}=49.38 \pm 5.14 \mathrm{mg} / \mathrm{L}\right.$ and $\left.\mathrm{HC}{ }_{50}>256 \mathrm{mg} / \mathrm{L}\right)$. Neither uperin 3.6 nor its analogs exhibited toxicity to human red blood cells $\left(\mathrm{HC}_{10}\right.$ and $\mathrm{HC}_{50}$ of more than $256 \mathrm{mg} / \mathrm{L}$ ) (Table 4).

The cytotoxicity of the designed peptides against human vaginal (VK2/E6E7) and esophagus (Het-1A) epithelial cell lines was assessed after 24, 48 and 72 hours of treatment by using MTS assay (Table 5). Significant toxic effects of the hybrid peptides and uperin 3.6 analogs were observed against VK2/E6E7 and Het-1A cell lines. Hybrid peptides and uperin 3.6 analogs reduced the cell viability to $50 \%$ at concentrations below the MIC doses. Uperin 3.6 and its analogs were highly toxic to both cell lines with low $\mathrm{IC}_{50}$ values although they did not exert haemolytic activity on human erythrocytes.

\section{Molecular interaction of designed peptides with SAP 1, SAP 5 and exo-beta-(1, 3)-glucanase}

Results obtained from rigid docking performed by Autodock Vina software indicated that all peptides bound to three selected target proteins respectively were within the negative binding affinity range (Supplementary data: Table S2). Peptides with greater negative binding affinity range indicate stronger binding affinities with target proteins. In comparison with peptides in respective series, KU3 and Upn-lys5 with lower MIC values showed higher binding affinities for three target proteins and hence, they were selected for further analysis. Parent peptide KABT-AMP and uperin 3.6 were included as a control (Supplementary data: Table S2).

The superpositions of minimized docking structures for the peptides were shown in Figure 4. The docking conformation and the interaction between potential target proteins (sap1, sap5 and exo- $\beta$ $(1,3)$-glucanases (Exg)) with peptides are shown in Figure 5, 6 and 7. The green dotted line represents hydrogen bonds of the complexes. Based on the docking conformation, KU3 and KABT-AMP displayed similar number of hydrogen bonds with sap1 (Figure 5). Docking conformation of KU3 showed hydrogen bonding between sap5 at Tyr14, Ile30, Asp37, Asp54, Lue124, Glu132, Asp132 and Glu295 residues (Figure 6). For Exg, hydrogen bonds formed between KU3 at Glu27, Tyr29 and Glu372 residues (Figure 7). On the other hand, Upn-lys5 formed more hydrogen bonds with the target proteins than Uperin3.6. Three hydrogen bonds formed between Upn-lys5 and sap1 at Asp191 whilst none was noted for Uperin3.6 (Figure 5). Upn-lys5 formed hydrogen bonds with sap5 at Glu10, Asp32, Tyr84, Gly85, Asp86 and Asp218 residues, as seen in Figure 6.

The total interaction energy of the target proteins and peptides, which is the sum of the van der Waals (VDW) and electrostatic energy within $3 \AA$, is tabulated (Supplementary data: Table S3, S4 and S5). KU3 shows strong binding interactions with the target proteins as compared to other peptides. For sap1, KABT-AMP showed slightly stronger interaction than KU3 mainly due to the electrostatic interaction with Asp37, Asp191 and ASP214. KU3 was found to exhibit interaction with Glu10, Asp32, Asp37, Asp54, Asp86, Glu295 and Asp308 of sap5 while for Exg, KU3 has interactions with Asp145, Asn191, Glu192, Gly291, Gly292, Asn299 and Asp318 residues. All peptides demonstrated interactions with Glu192 and Glu292 of Exg since both residues are catalytic sites. From the result, Upn-lys5 showed higher total interaction energy than Uperin3.6 for sap1 $(-453.603 \mathrm{kcal} / \mathrm{mol})$, sap5 $(-1004.134$ $\mathrm{kcal} / \mathrm{mol})$ and $\operatorname{Exg}(-627.185 \mathrm{kcal} / \mathrm{mol})$.

\section{Discussion}

The increased incidence of invasive fungal infections and the emergence of antifungal drug resistance in Candida spp., particularly against echinocandins and azoles, have prompted the development of alternative antifungal agents ${ }^{12}$. Antimicrobial peptides (AMPs) can be promising candidates for novel antifungal agents due to their broad-spectrum activities against pathogens and low chances of developing antimicrobial resistance ${ }^{23}$. Some naturally occurring antifungal peptides such as polymyxin, melittin and protegrin demonstrated potent antimicrobial activity, but their therapeutic application is limited due to the toxicity effect on mammalian cells ${ }^{24-26}$. Therefore, sequence modification of natural peptides with known activity is essential to enhance the antimicrobial activity and reduce the toxicity of peptides. In this study, KABT-AMP, a synthetic peptide and uperin 3.6, a natural peptide isolated from the Australian toadlet, Uperoleia mjobergii were selected as a template to design a new class of peptides ${ }^{20,21}$. Physicochemical parameters such as cationicity, hydrophobicity and amphipathicity were taken into consideration for peptide design (Table 1).

Hydrophobicity is one of the crucial parameters responsible for the antimicrobial activity of AMPs. It facilitates the AMP-membrane interaction and governs the extent of partition of AMPs into the cell 
(a)

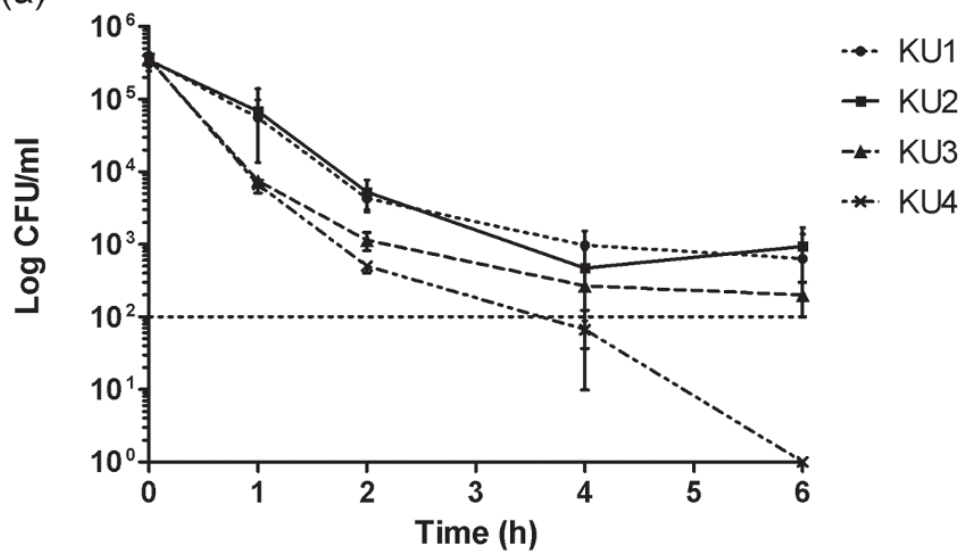

(a)

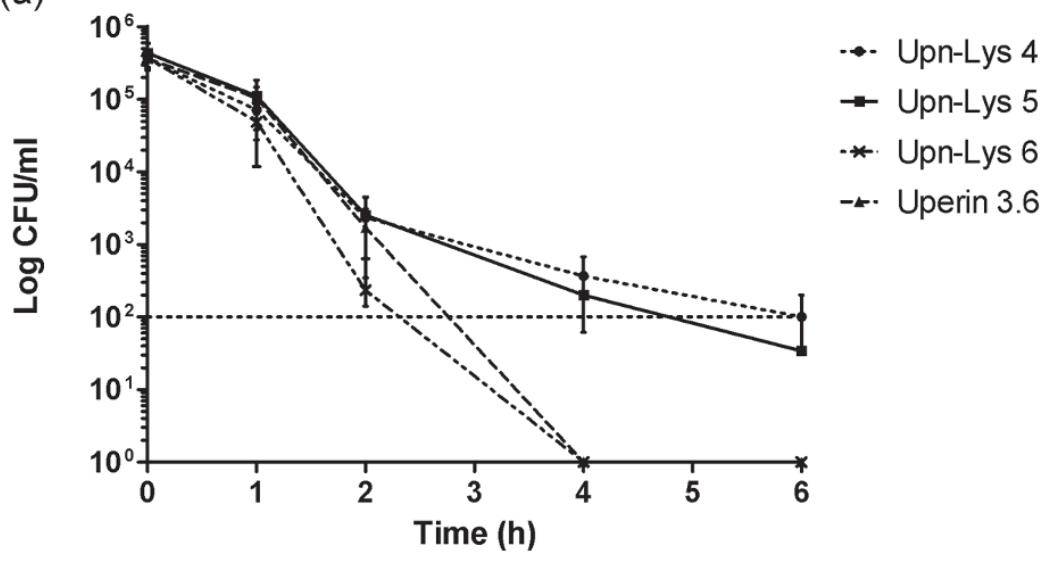

(a)

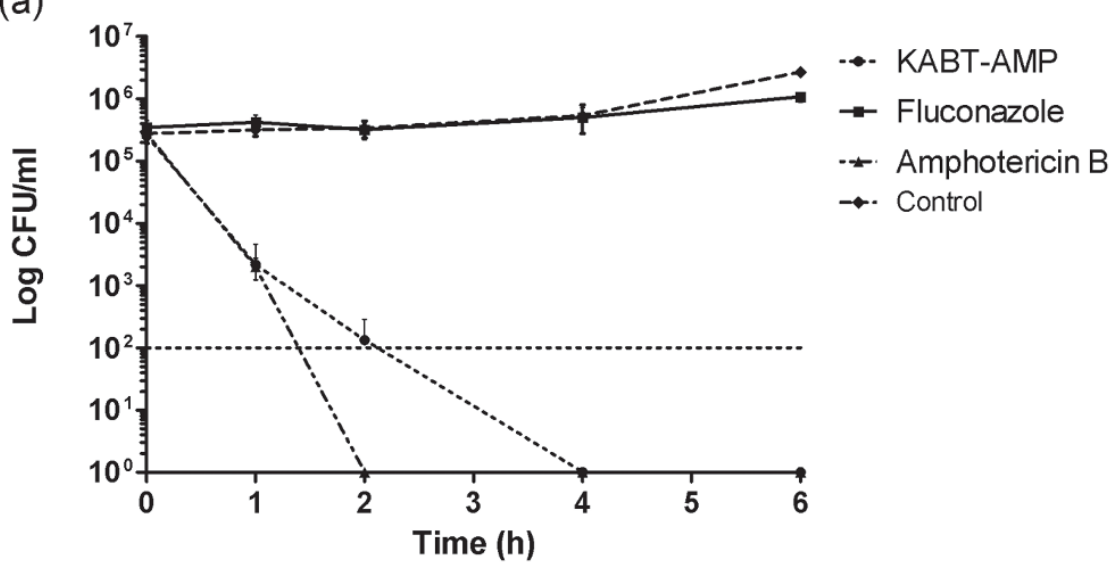

Figure $2 \mid$ Killing kinetics of the designed peptides and antifungals against $C$. albicans SC 5314. Standardized yeast cells suspensions were exposed to a final concentration of two times the previously determined MIC of the tested strain. At determined time intervals, samples were serially diluted and plated for colony counts. Each data point represents mean result \pm standard deviation (error bars) from three experiments.

membrane. Studies showed that enhancement of the overall hydrophobicity increased the antimicrobial potency of $\mathrm{AMPs}^{27-29}$. Based on GRAVY score, KU1 had the highest hydrophobicity (positive GRAVY score) among the hybrid peptides. However, the MIC values obtained show that KU2 was more potent than KU1 although KU2 is more hydrophilic (negative GRAVY score). By observing the helical projection of the peptides, we found that the enhancement of anticandidal activity of KU2 can be due to the number of tryptophan (Trp) residues incorporated in the peptide sequences. Tryptophan
(Trp) is a hydrophobic residue that has a strong preference for the interfacial region of the lipid bilayers of the yeast cell membrane ${ }^{30}$. Replacement of $\mathrm{Val}^{10}$ at KU1 by Trp residue resulted in three Trp residues $\left(\operatorname{Trp}^{3}, \operatorname{Trp}^{6}\right.$ and $\left.\operatorname{Trp}^{10}\right)$ positioned at the nonpolar face of KU2 and hence, enhanced the anchoring of the peptide to membrane (Figure 1b). By comparing KU2 and KU3, substitution of Asn ${ }^{12}$ by Lys residue at the hydrophilic face has no effect on the anticandidal activity (Figure 1c). KU4 demonstrated the least anticandidal potency among the hybrid peptides as a result of the substitution 
(a)

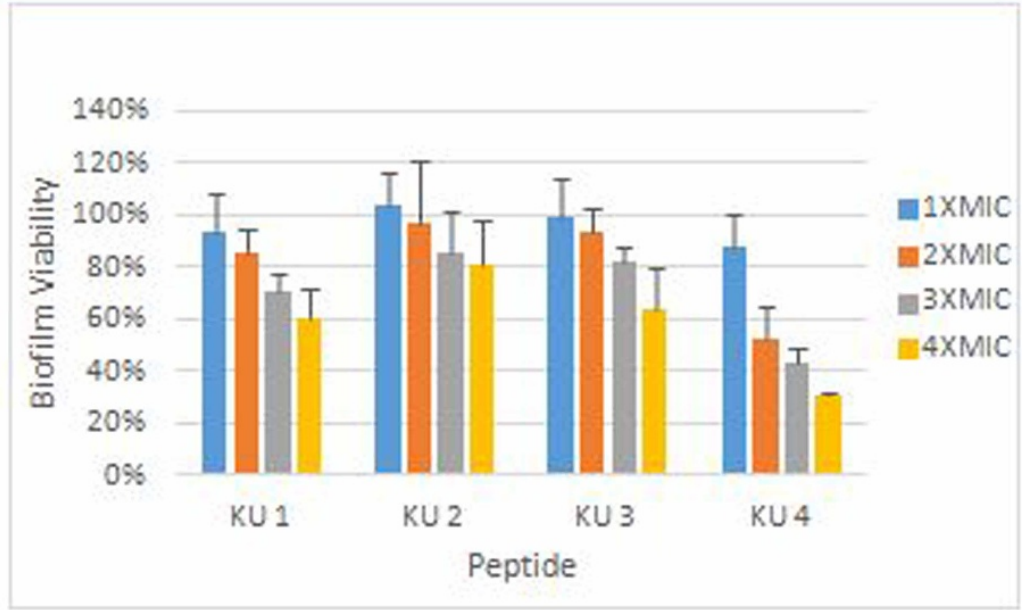

(b)

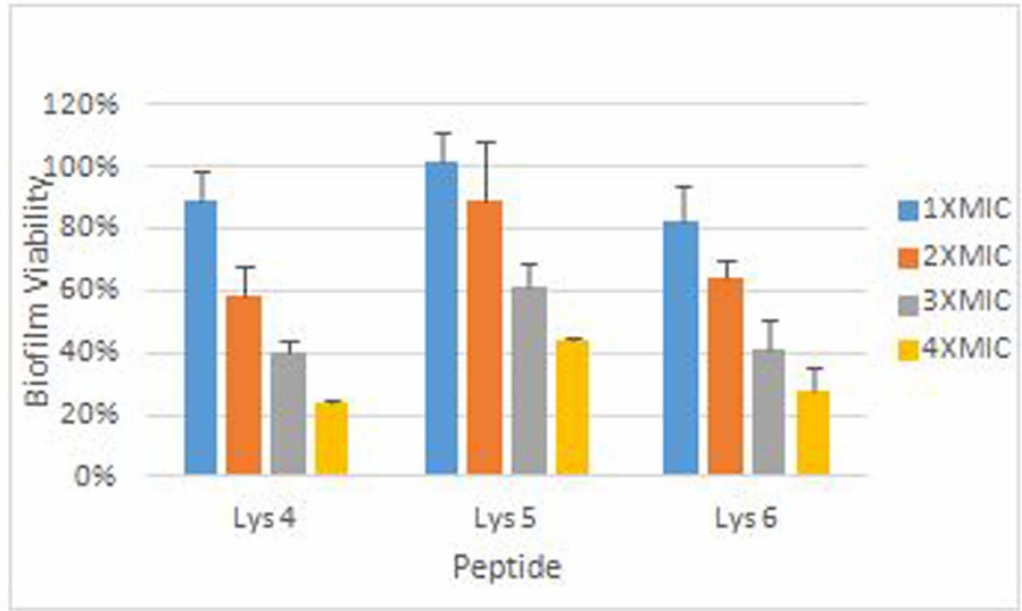

(c)

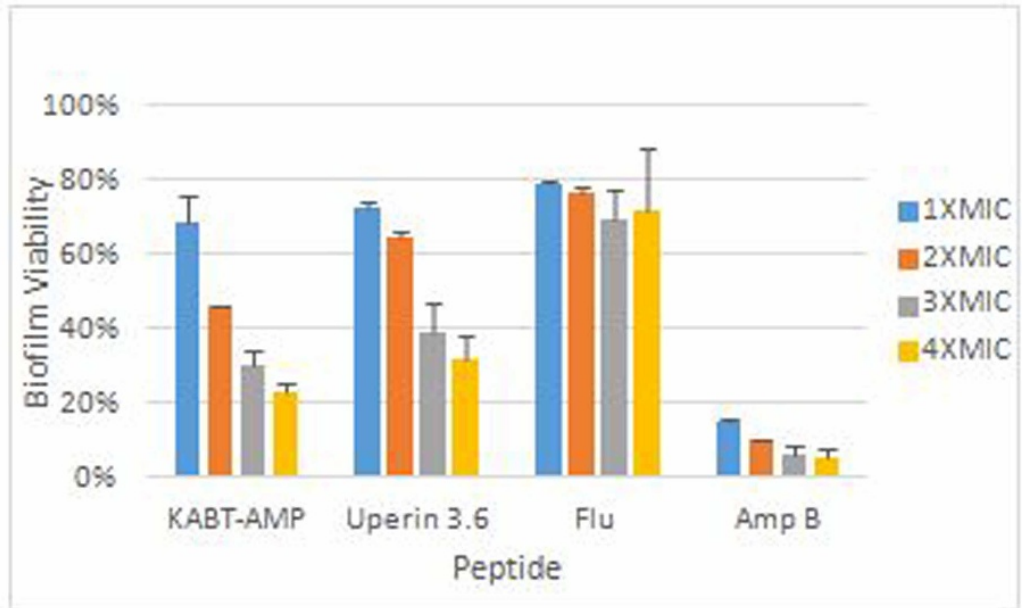

Figure 3 Biofilm viability after treatment with peptides at concentration ranging from $1 \times$ to $4 \times$ MIC against $C$. albicans SC5314 strain. Each data point represents mean result \pm standard deviation (error bars) from two experiments in triplicates.

of hydrophobic $\mathrm{Val}^{13}$ by Lys residue which reduced the hydrophobicity of the peptide (Figure 1d). These results are consistent with a previous study ${ }^{18}$.

Cationic residues on the peptide promote the electrostatic attraction of the peptides to the anionic phospholipids in fungal membranes such as phosphatidylserine and phosphatidylinositol or wall components such as mannoproteins in yeast ${ }^{31,32}$. According to the
MIC results of uperin 3.6 lysine-substituted analogues, substitution of a single lysine residue into the parent peptide (Upn-lys4) exhibited no improved activity against C. albicans strains and C. krusei. Upn-lys5 and Upn-lys6 displayed two-fold increase in potency against $C$. albicans as one or two Lys residues were substituted into the parent peptide. This suggested that further increase in the number of positive charge residue on Upn-lys6 is required as it may 
Table $3 \mid$ Antibiofilm activity of designed peptides and conventional antifungals against Candida albicans

Peptides

BEC-2 values $(\mathrm{mg} / \mathrm{L})$

\section{KU1}

$\mathrm{KU} 2$

KU3

KU4

Upn-lys4

Upn-lys5

Upn-lys6

Uperin 3.6

KABT-AMP

Fluconazole

Amphotericin B

enhance the mediation of interaction of peptides with thick yeast cell walls.

Rapid killing effect is one of the important features of AMPs. Based on the results obtained (Figure 2), we suggest that the killing kinetics of the designed peptides correlated with their cationicity. KABTAMP with a net charge of +10 demonstrated rapid killing rates with fungicidal effect ( $>99.99 \%$ killing) within 4 hours of incubation. KU4 $(+7)$ reached the fungicidal endpoint at 6 hours of test period, showing better killing effect as compared to KU1 (+5), KU2 (+5) and KU3 $(+6)$ although KU4 had the highest MIC value among the hybrid peptides (Figure 2a). In term of uperin 3.6 analogues, the killing effects were enhanced as the number of cationic lysine residues increased (Figure 2b). Previous studies on magainin analogues reported that increased cationicity increased the translocation of peptides across the membrane ${ }^{33}$. However, uperin 3.6 with +3 net charge displayed an exception in this case. It exhibited fungicidal effect after 4 hours of test period which is almost similar to the killing kinetic demonstrated by Upn-lys6. This is probably due to the presence of negatively charged aspartic acid, D in uperin 3.6, which may contribute to the electrostatic interaction of the peptide with yeast cell membrane.

C. albicans is the most common fungal species associated with biofilm formation ${ }^{34}$. Mature Candida biofilms display a complex three-dimensional structure consisting of a dense network of yeasts, hyphae and pseudohyphae and are frequently encountered on the surface of most implanted medical devices ${ }^{34}$. Candida biofilms are more resistant to host defense mechanism and antifungal agents such as fluconazole and amphotericin B. The resistance can be up to 1000fold greater than planktonic cells, depending on both drug and yeast

Table 4 | Haemolytic activity of peptides and conventional antifungals on human erythrocytes

\begin{tabular}{lcc} 
& \multicolumn{2}{c}{ Haemolytic activity $(\mathrm{mg} / \mathrm{L})$} \\
\cline { 2 - 3 } Peptide or antifungal & $\mathrm{HC}_{10}{ }^{a}$ & $\mathrm{HC}_{50}{ }^{a}$ \\
\hline KU1 & $8.07 \pm 1.60$ & $58.19 \pm 2.04$ \\
KU2 & $7.33 \pm 0.73$ & $57.71 \pm 9.80$ \\
KU3 & $5.65 \pm 0.85$ & $55.20 \pm 11.90$ \\
KU4 & $49.38 \pm 5.14$ & $>256$ \\
Upn-lys4 & $>256$ & $>256$ \\
Upn-lys5 & $>256$ & $>256$ \\
Upn-lys6 & $>256$ & $>256$ \\
KABT-AMP & $4.67 \pm 2.09$ & $81.23 \pm 8.92$ \\
Uperin 3.6 & $>256$ & $>256$ \\
Fluconazole & $>256$ & $>256$ \\
Amphotericin B & $5.79 \pm 1.59$ & $60.94 \pm 15.88$ \\
\hline
\end{tabular}

${ }^{\circ} \mathrm{HC}_{10}$ and $\mathrm{HC}_{50}$ are concentration that causes $10 \%$ and $50 \%$ haemolysis of human erythrocytes measured after 1 hour of incubation of erythrocytes with peptides. species $^{35,36}$. For AMPs, Burrows et al demonstrated that the most potent peptide in their studies, $\mathrm{dF} 21-10 \mathrm{~K}$, was less effective at $5 \times$ MIC and a concentration of $10 \times$ MIC was required to eradicate biofilm cells completely ${ }^{37}$. In our study, although KU1, KU2 and KU3 showed potent anticandidal activity against planktonic cells, they were unable to reduce biofilm viability to $50 \%$ even at $4 \times \mathrm{MIC}$ (BECs $>4 \times$ MIC) (Table 3 ). In contrast, KU4 and KABT-AMP with higher MIC values demonstrated potent antibiofilm activity. In term of uperin 3.6 analogues, we found that the BEC- 2 values reduced as the number of lysine substituted increased. Hence, we suggest that the enhanced antibiofilm activity of the peptides against C. albicans may have a correlation with the increased cationicity of the peptides.

Drug combination therapy which involves the use of two or more drugs with separate mode of action can potentially improve the current available antimicrobial treatment. Combination regimens, in certain cases could potentially improve the efficacy, reduce toxic side effects and the cost of each individual drug and limit the development of antifungal resistance as shown in monotherapy ${ }^{38}$. A number of studies reported that AMPs exhibited synergistic effect with conventional antifungal agents ${ }^{38-40}$. In the current study, all peptide-amphotericin B combinations demonstrated synergistic activity (FICI $\leq 0.5)$ when tested on C. albicans SC5314 strain. For C. albicans ATCC 90028 strain, all peptides exhibited synergistic effects with amphotericin B with the exception of Upn-Lys6 (FICI 0.58 ) and uperin 3.6 (FICI 0.67). With regard to fluconazole, there were four peptide-fluconazole combinations (KU4, KABT-AMP, Upn-lys6 and uperin 3.6) and only one KU4-fluconazole combination displayed synergistic effects against C. albicans SC5314 strain and ATCC 90028 strain, respectively. In general, two compounds that interact in a synergistic way most probably exert antimicrobial activity in a different mechanism of action. Amphotericin B demonstrated fungicidal effect by binding to the fungal cell membrane ergosterol moiety and causing porosity on the fungal membrane. Fluconazole is a fungistatic azole-based antifungal which interferes with the key enzyme involved in the ergosterol biosynthesis and thereby inhibits the formation of ergosterol. In term of AMPs, various mechanisms of action have been proposed which include the ability of AMPs to damage cell membrane, interact with intracellular targets such as inhibition of cell wall, nucleic acid and protein synthesis, and induction of apoptosis ${ }^{41}$. Therefore, as the peptides synergistically interacted with fluconazole and amphotericin B, this might indicate that their mode of actions differ from both antifungals, and the synergistic effects could be attributed to the combination of two different mechanism of actions.

Although the peptides designed in this study demonstrated improved anticandidal activity, their therapeutic potential was hindered by toxicity. KU1, KU2 and KU3, which had the greatest hydrophobicity among hybrid peptides, demonstrated significant toxicity to red blood cells with low $\mathrm{HC}_{10}$ and $\mathrm{HC}_{50}$ values. Peptides with higher hydrophobicity tend to penetrate deeper into the hydrophobic core of red blood cell membrane and cause stronger haemolytic activities. In term of KU4, less haemolytic activity was observed due to the overall low hydrophobicity. Besides that, we found that nonpolar helix face of KU4 was disrupted by Lys ${ }^{13}$ residue and hence, reducing the penetration of the peptide into the cell membrane $e^{27,42}$. In term of uperin 3.6 analogues, no haemolytic activity was observed although they exhibited greater overall hydrophobicity compare to other hybrid peptides. Hence, the haemolytic activity was probably attributed to the tryptophan residues present in the hybrid peptides ${ }^{18}$. However, uperin 3.6 analogues induced significant toxicity against normal vaginal cell and esophagus epithelial cell lines although they did not lyse the erythrocytes. We propose that the mechanism of action of uperin 3.6 and its analogues could be organelle or nucleus dependent as they did not show toxicity effect on enucleated red blood cells ${ }^{18}$. Therefore, further investigations on 
Table 5 | Cytotoxicity of peptides and conventional antifungals on VK2/E6E7 and Het-1A cell lines

$$
\mathrm{IC}_{50}(\mathrm{mg} / \mathrm{L})
$$

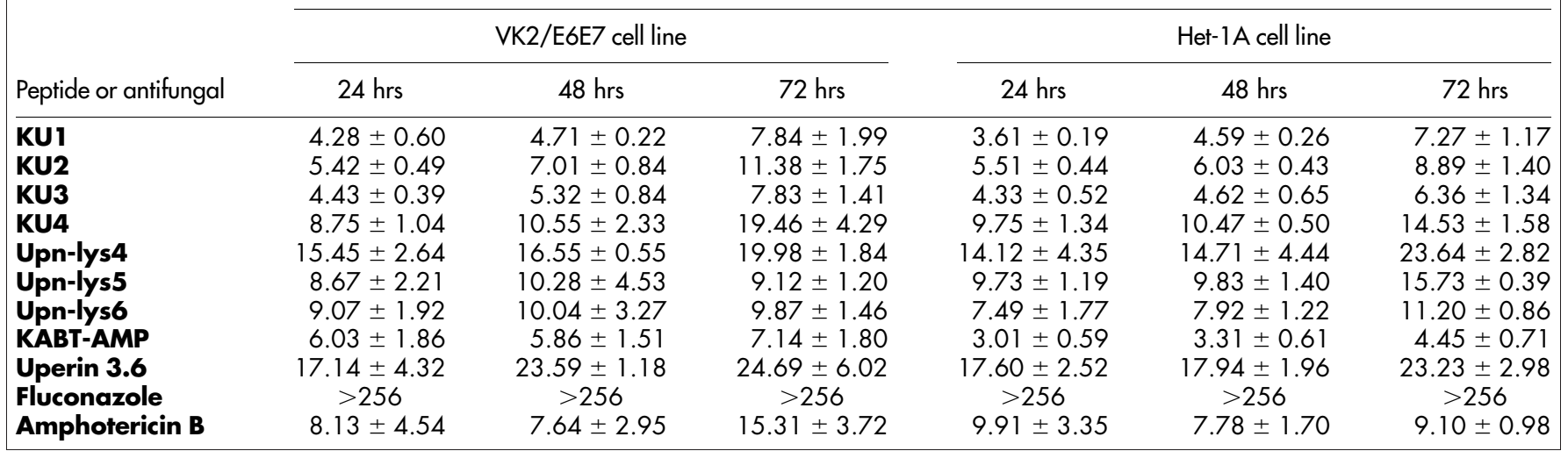

these peptides are needed to elucidate the mechanisms of action of these peptides to kill Candida cells.

Molecular docking investigations enable clarifications of the binding mode of the peptides with the possible target proteins (sap1, sap5 and Exg). According to docking results, all peptides bound well with the target proteins since they demonstrated negative binding affinities to the target proteins (Supplementary data: Table S2). The interaction energy which is the sum of van Der Waals (VDW) and electrostatic interaction determines the interaction between peptides and target proteins. Based on the results of the interaction energy obtained, we suggest that KU3, KABT-AMP, Upn-lys5 and uperin 3.6 exhibit stronger interaction with sap5 as compared to sap1 and Exg.

\section{Conclusion}

This study provides us a better understanding of the structure-activity relationship of antifungal peptides although the therapeutic applications of the peptides are limited due to toxicity. Several parameters such as hydrophobicity, the number of tryptophan residues, amphipathicity and cationicity are crucial for anticandidal activity of the peptides. We demonstrated that the antibiofilm activity and the killing kinetics are correlated with the cationicity of the peptides. The designed peptides also showed synergistic effects when used in combination with conventional antifungals and hence, this may result in reduced probability of resistance development in Candida spp. against the conventional antifungals. Further investigations are needed to elucidate the mechanism of action and mode of killing of the peptides.

\section{Methods}

Yeast strains and growth conditions. C. albicans strains SC5314 and ATCC 90028, C. krusei ATCC 6258 and C. parapsilosis ATCC 22019 were used in the study. The strains were stored at $-80^{\circ} \mathrm{C}$ in nutrient broth supplemented with $2.0 \%$ glycerol stock. Prior to experimentation, each strain was streaked for single colonies on Sabouraud Dextrose (SDA) agar plates and incubated overnight at $37^{\circ} \mathrm{C}$.

Peptide synthesis. Peptides were synthesized to $>90 \%$ purity by Mimotopes Pty Ltd (Clayton, Victoria, Australia. http://www.mimotopes.com/). The characterization and purity estimation of the peptides were performed by using electrospray mass spectrometry (ESMS) and reverse phase high performance liquid chromatography (RP-HPLC). All peptides were dissolved in sterilized water to $10 \mathrm{mg} / \mathrm{ml}$ and stored in aliquots at $-20^{\circ} \mathrm{C}$.

MIC determinations. Antifungal activity of the designed peptides was determined according to a standardized broth microdilution method (Clinical and Laboratory Standards Institute (CLSI) document M27-A2). Briefly, the yeast colonies from 24hour-old cultures of Candida species were picked and resuspended in $5 \mathrm{~mL}$ of sterile $0.145 \mathrm{~mol} / \mathrm{L}$ saline and adjusted to cell density of $1 \times 10^{6}$ to $5 \times 10^{6} \mathrm{cells} / \mathrm{ml}$. The yeast stock suspension was then diluted to obtain a starting inoculum of $5.0 \times 10^{2}$ to $2.5 \times 10^{3}$ cells $/ \mathrm{ml}$. Conventional antifungals such as amphotericin B (Sigma, USA) and fluconazole (Sigma, USA) were included in this study as controls and to compare the anticandidal activity with the designed peptides. The drugs were dissolved in DMSO and prepared to a stock concentration of $25 \mathrm{mg} / \mathrm{L}$ and $50 \mathrm{mg} / \mathrm{L}$, respectively. Peptides and the antifungals were then serially diluted in RPMI 1640 growth medium buffered with morpholinepropanesulfonic acid (MOPS) in volume of $100 \mu \mathrm{L}$ per well, giving final concentrations ranging from $256 \mathrm{mg} / \mathrm{L}$ to $0.5 \mathrm{mg} / \mathrm{L}$ in sterile $\mathrm{U}$ bottomed 96-well polypropylene microplates. $100 \mu \mathrm{L}$ of standardized yeast suspension was then added to each well. Plates were incubated for 48 hours at $37^{\circ} \mathrm{C}$. The minimum inhibitory concentration (MIC) was defined as the lowest concentration that inhibited $90 \%$ growth of Candida species. The MICs were determined three times and each time in duplicate.

Time killing assay. Killing kinetics of the peptides were determined by diluting the peptides with RPMI medium to a final concentration of 2 times the previously determined MIC for the strain to be tested. A fungal suspension was adjusted to a 0.5 McFarland turbidity standard with cell density of $1 \times 10^{6}$ to $5 \times 10^{6}$ cells $/ \mathrm{ml} .100 \mu \mathrm{L}$ of adjusted yeast suspension was exposed to $900 \mu \mathrm{L}$ of RPMI medium containing peptide, yielding a starting inoculum of approximately $10^{5}$ cells $/ \mathrm{ml}$. The solutions were incubated at $37^{\circ} \mathrm{C}$ with agitation. At the predetermined time interval of $0,1,2,4$ and 6 hours, $10 \mu \mathrm{L}$ or $30 \mu \mathrm{L}$ of the samples were removed, serially diluted with
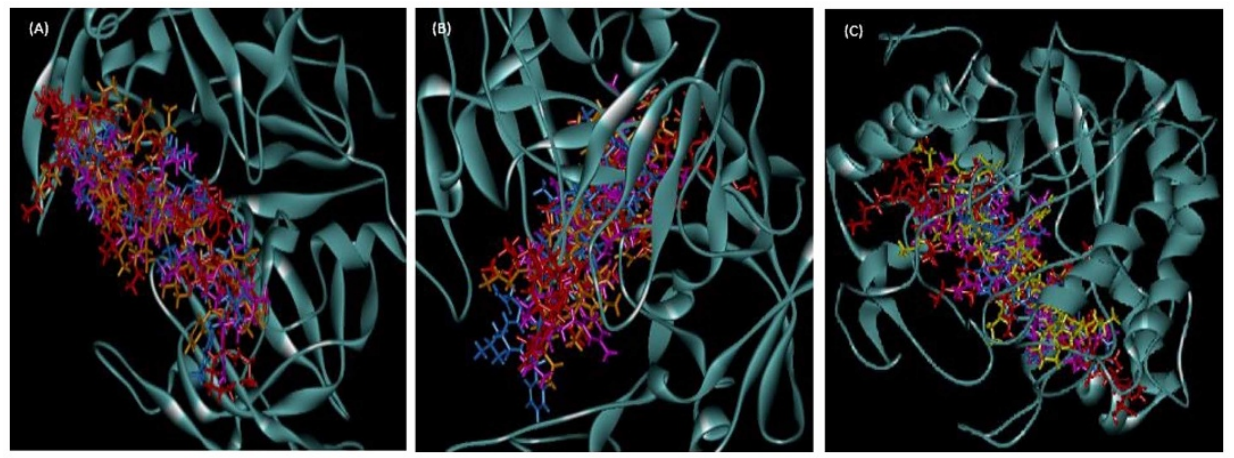

Figure $4 \mid$ The superposition of peptide structure of KABT-AMP (red), KU3 (orange), uperin3.6 (blue) and Upn-lys5 (purple) in (A) sap1, (B) sap5 and (C) $\beta$-1,3-exoglucanase docking complexes. 


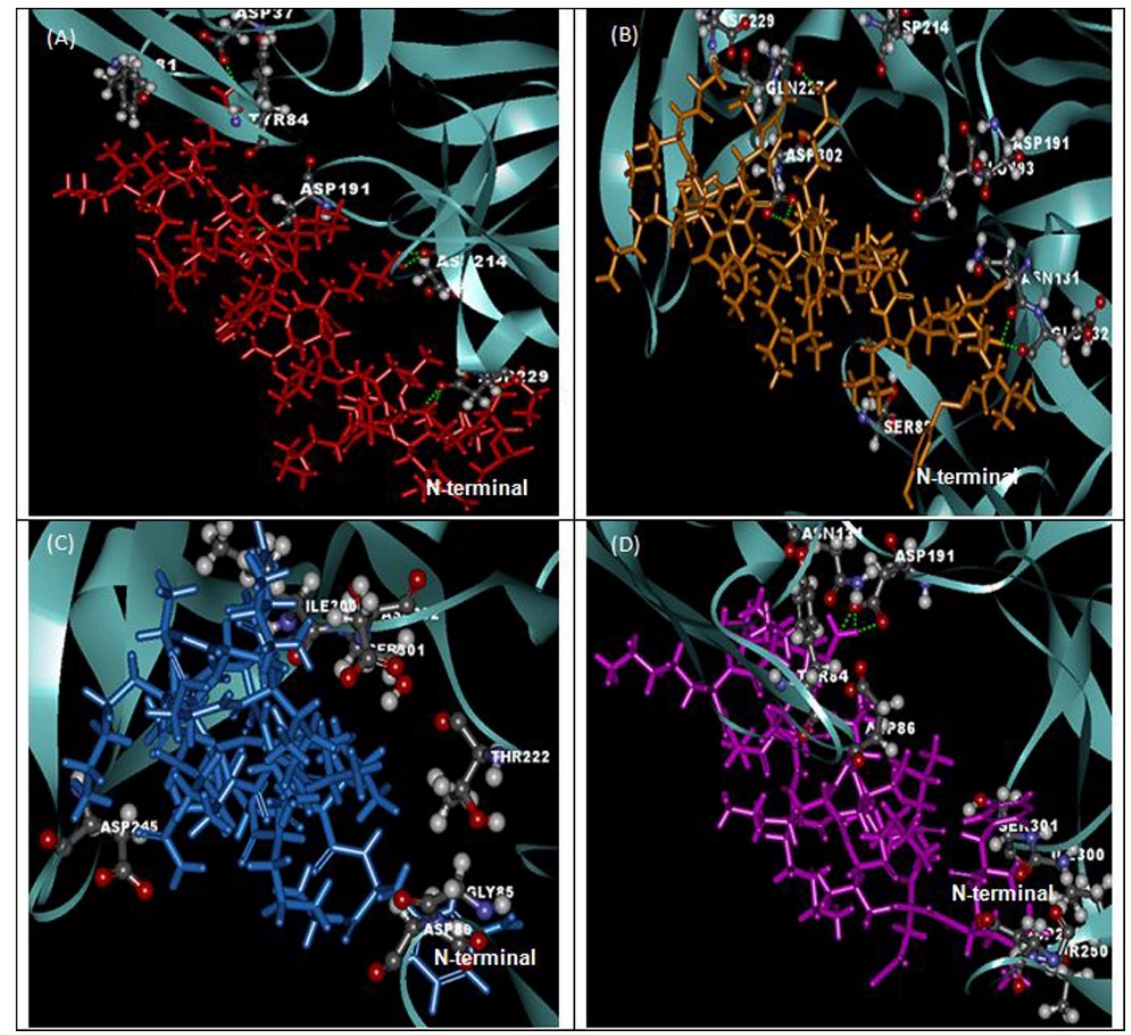

Figure $5 \mid$ The docking conformation and sap1 amino acid interactions with (A) KABT-AMP, (B) KU3, (C) uperin3.6 and (D) Upn-lys5.

phosphate-buffered saline (PBS) and plated on SDA plates to allow colony counts after 24 hours of incubation. Controls for yeast growth and antifungal agents were also performed. The lower limit of accurate and reproducible quantitation was $100 \mathrm{CFU} / \mathrm{ml}$. Results were obtained from three independent experiments.
Biofilm reduction assay. Biofilms of C. albicans were formed on commercially available pre-sterilized, polystyrene, flat bottomed 96 well microtitre plates as described by Jin et al with modification ${ }^{43}$. Firstly, a standardized yeast suspension $\left(10^{7}\right.$ cells $/ \mathrm{ml}$ ) of C. albicans SC5314 was prepared by suspending colonies from 24-hours
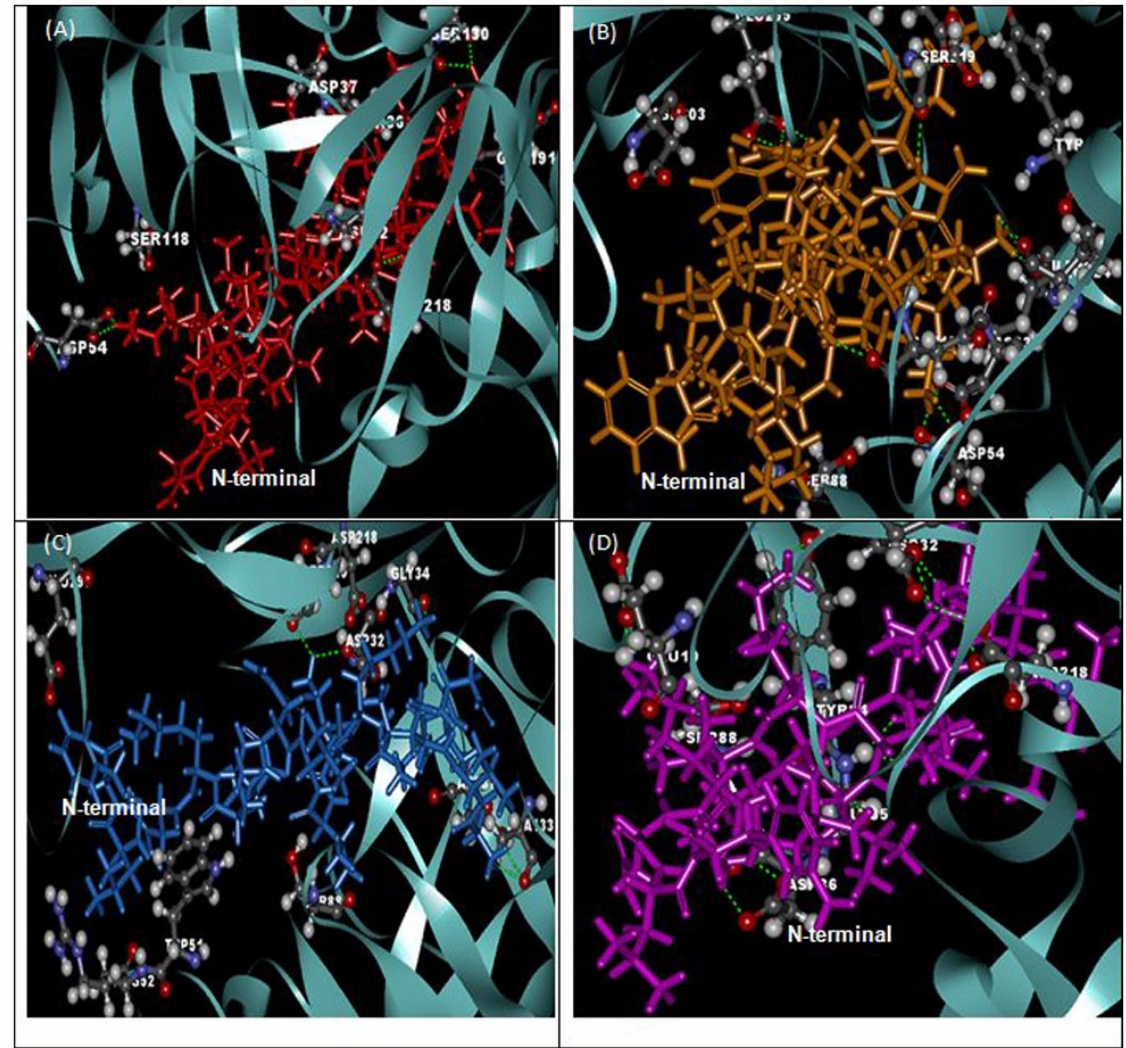

Figure $6 \mid$ The docking conformation and sap5 amino acid interactions with (A) KABT-AMP, (B) KU3, (C) uperin3.6 and (D) Upn-lys5. 

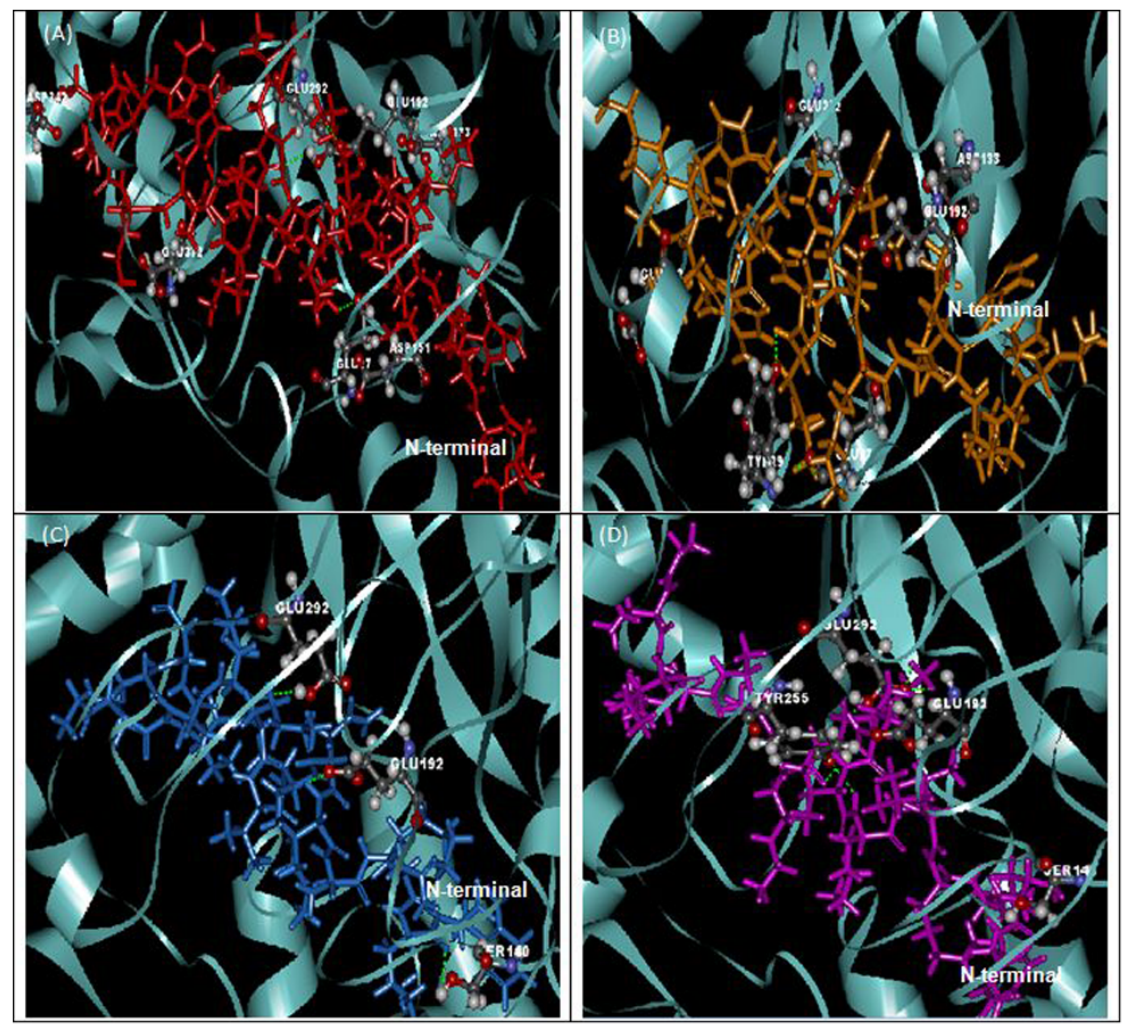

Figure $7 \mid$ The docking conformation and $\beta$-1,3-exoglucanase amino acid interactions with (A) KABT-AMP, (B) KU3, (C) uperin3.6 and (D) Upn-lys5.

old culture in RPMI 1640 medium and adjusted to an optical density of $0.38-0.39$ at $520 \mathrm{~nm} .100 \mu \mathrm{L}$ of yeast suspension was dispensed into each well of a microtitre plate using a multichannel pipette and the plates were incubated in a shaking incubator at $37^{\circ} \mathrm{C}$ with $75 \mathrm{rpm}$ for 90 minutes to allow adherence of yeast on the surface of each well. After the adhesion phase, the non-adherent cells were removed and each well was washed twice with $150 \mu \mathrm{L}$ PBS. $100 \mu \mathrm{L}$ of RPMI 1640 medium was transferred to each washed well and the plates were incubated at $37^{\circ} \mathrm{C}$ in a shaking incubator at $75 \mathrm{rpm}$ for 24 hours to allow biofilm formation. Following biofilm phase, the medium was aspirated and each well was washed twice gently with $200 \mu \mathrm{L}$ PBS to remove non-adherent cells. Residual PBS was removed by inverting the plates over an absorbent paper before addition of peptides. $200 \mu \mathrm{L}$ of each peptide with concentrations ranging from 1 to 4 times of the MIC determined previously was added to respective wells and the plates were incubated as described above for $24 \mathrm{~h}$. Antifungal agent-free wells and biofilm-free wells were included as positive and negative controls. After treatment with peptides, the medium was removed and each well was washed twice with $200 \mu \mathrm{L}$ PBS. The biofilm formation was quantified by using XTT reduction assay as described below. Each experiment was repeated three times in duplicate.

XTT reduction assay was performed according to the method adapted from Jin et al. ${ }^{44}$ Briefly, XTT (Sigma) was dissolved to a concentration of $1 \mathrm{mg} / \mathrm{ml}$ using sterile PBS. XTT solution was then filter-sterilized using a $0.22 \mu \mathrm{m}$-pore-size filter and kept at $-70^{\circ} \mathrm{C}$ prior to use. $0.4 \mathrm{mM}$ menadione solution was prepared by dissolving menadione (Sigma) with acetone. The menadione solution was filter-sterilized and kept at $-70^{\circ} \mathrm{C}$ before use. Prior to each assay, XTT solution was thawed and mixed with menadione solution at a volume ratio of $20: 1$. After washing, a total volume of $200 \mu \mathrm{L}$ of XTT-menadione mixture $(158 \mu \mathrm{L}$ of PBS, $40 \mu \mathrm{L}$ of XTT and $2 \mu \mathrm{L}$ of menadione) was added to each prewashed biofilm and control wells. The plates were incubated in the dark for 2 hours at $37^{\circ} \mathrm{C} .100 \mu \mathrm{L}$ of the solution was transferred to new wells and the colorimetric change in the solution was measured using a microtiter plate reader at $490 \mathrm{~nm}$. Antibiofilm activity of the peptides and conventional antifungals was expressed as the biofilm-eradicating concentration 2 (BEC-2), which is defined as the minimum concentration of the peptides resulting in $50 \%$ reduction of the biofilm viability compared to the growth control.

Chequerboard antifungal analysis. Peptide-peptide and peptide-antibiotic interactions were assessed in sterile U-bottomed 96-well polystyrene microplates using a chequerboard method with minor modification. $50 \mu \mathrm{L}$ of eight serial twofold dilutions of peptide and ten serial twofold dilutions of antifungal agent with beginning concentration at $4 \times$ MIC were prepared in each well. A fixed concentration of $0.25 \times$ MIC of the peptide was added in a volume of $50 \mu \mathrm{L}$ into each column. Each well of the plates was inoculated with $5.0 \times 10^{2}$ to $2.5 \times 10^{3} \mathrm{cells} / \mathrm{ml}$ of the yeast suspension. The plates were incubated at $37^{\circ} \mathrm{C}$ for 48 hours. The fractional inhibitory concentration (FIC), defined as MIC of the drug used in combination divided by the MIC of drug tested alone, was determined ${ }^{45}$. The effects of the peptidepeptide and peptide-antibiotic combinations were expressed in term of FIC index (FICI), where by

$$
\text { FICI }=\text { FICA }+ \text { FICB }=\frac{\text { MIC drug A in combination }}{\text { MIC drug A alone }}+\frac{\text { MIC drug B in combination }}{\text { MIC drug B alone }}
$$

The FICI $\leq 0.5$ was interpreted as synergism; while FICI $>0.5-4$ was an indication of no interaction; and FICI $>4$ was interpreted as antagonism.

Haemolytic assay. Freshly collected human blood with heparin was centrifuged to remove the buffy coat. The erythrocytes were washed three times with PBS, centrifuged for $10 \mathrm{~min}$ at $2000 \mathrm{rpm}$ at $10^{\circ} \mathrm{C}$, and resuspended in PBS to $4 \%(\mathrm{vol} / \mathrm{vol})$ Peptides were serially diluted in PBS to a concentration ranging from $256 \mathrm{mg} / \mathrm{L}$ to $0.5 \mathrm{mg} / \mathrm{L}(100 \mu \mathrm{L})$ in U-bottomed 96-well polystyrene microplates and $100 \mu \mathrm{L}$ of the erythrocyte suspension was added to each well. PBS and $0.1 \%$ Triton X-100 were used as agents to induce 0 and $100 \%$ haemolysis, respectively. Plates were incubated for 1 hour at $37^{\circ} \mathrm{C}$ and centrifuged at $2000 \mathrm{rpm}$ for $10 \mathrm{~min}$. The supernatant $(100 \mu \mathrm{L})$ was transferred to a 96-well flat-bottomed polystyrene plate, and the release of haemoglobin was monitored by measuring the absorbance at $560 \mathrm{~nm}$ using a microplate reader. Results were repeated three times and each time in duplicate. The percentage of haemolysis was calculated using the following formula:

$$
\text { Haemolysis }(\%)=\left(A_{p}-A_{0} / A_{100}-A_{0}\right) \times 100
$$

where $A_{p}$ and $A_{100}$ represent the absorbance of erythrocytes treated with peptide and $0.1 \%$ Triton $\mathrm{X}-100 . \mathrm{A}_{0}$ is the absorbance of erythrocytes without treatment.

Cytotoxicity against normal human cell lines. The human normal vaginal epithelial cell line VK2/E6E7 (ATCC ${ }^{\circledR}$ CRL-2616 ${ }^{\mathrm{TM}}$ ) and human normal esophagus epithelial cell line Het-1A (ATCC ${ }^{\circledR}$ CRL-2692 ${ }^{\mathrm{TM}}$ ) were used for cytotoxicity testing. VK2/E6E7 cell line was grown in Keratinocyte-Serum Free medium (GIBCO-BRL 17005-042) supplemented with $0.1 \mathrm{ng} / \mathrm{ml}$ human recombinant EGF, $0.05 \mathrm{mg} / \mathrm{ml}$ bovine pituitary extract, and $44.1 \mathrm{mg} / \mathrm{L}$ calcium chloride. Het-1A cell line was grown in flask coated with $0.01 \mathrm{mg} / \mathrm{ml}$ fibronectin, $0.03 \mathrm{mg} / \mathrm{ml}$ bovine collagen type 1 and $0.01 \mathrm{mg} / \mathrm{ml}$ bovine serum albumin and maintained in BEBM medium supplemented with BEGM (SingleQuots) except gentamicin-amphotericin B mix. VK2/E6E7 and Het-1A cells were seeded overnight at $1 \times 10^{4}$ cells/well in 96-well flat bottom microplates and treated with $100 \mu \mathrm{L}$ of serial diluted peptides at concentrations ranging from $256 \mathrm{mg} / \mathrm{L}$ to $0.5 \mathrm{mg} / \mathrm{L}$. Plates were incubated for 24,48 and 72 hours at $37^{\circ} \mathrm{C}$ under $5 \% \mathrm{CO}_{2}$. Cell viability was measured by using CellTiter $96^{\circledR}$ Aqueous NonRadioactive Cell Proliferation Assay (Promega, USA) and the colourimetric changes were determined at $490 \mathrm{~nm}$ using a microplate reader. $\mathrm{IC}_{50}$ was defined as the peptide 
concentration required for $50 \%$ reduction in cell viability. Results were recorded by averaging three repeated experiments and each experiment was performed in duplicate.

\section{Molecular docking study}

The Protein Data Bank (PDB) files of Sap1 (2QZW), Sap5 (2QZX) and exo-beta- $(1,3)$-glucanase $(1 \mathrm{CZ1})$ with respective resolution of $2.05 \AA, 2.50 \AA$, and $1.85 \AA$ were obtained from the RSCB protein data bank. Tertiary structure of the designed and template peptides was predicted using peptide tertiary structure prediction server (Pepstr, http://www.imtech.res.in/raghava/pepstr/) ${ }^{46}$. All selected target proteins and peptides underwent minimization by applying the CHARMm forcefield with Memony Rone partial charge using Discovery Studio Client 2.5, San Diego: Accelrys Software Inc ${ }^{47}$. The docking procedure was conducted by Autodock Vina with rigid docking ${ }^{48}$. Complex structures with strong binding affinity were further minimized and analyzed. The interaction energy of the complex within 3 Á was explored by interaction energy protocol of Discovery Studio Client 2.5, San Diego: Accelrys Software Inc.

1. Yapar, N. Epidemiology and risk factors for invasive candidiasis. Ther Clin Risk Manag 10, 95-105 (2014).

2. Dignani, M.-C., Solomkin, J. S. \& Anaissie, E. J. in Clinical Mycology 2nd edn, (eds. Anaissie, E. J., McGinnis, M. R. \& Pfaller, M. A.) Ch.8, 197-229 (Churchill Livingstone, Edinburgh, 2009).

3. Sievert, D. M. et al. Antimicrobial-resistant pathogens associated with healthcareassociated infections: summary of data reported to the National Healthcare Safety Network at the Centers for Disease Control and Prevention, 2009-2010. Infect Control Hosp Epidemiol 34, 1-14 (2013).

4. Wisplinghoff, H. et al. Nosocomial bloodstream infections in US hospitals: analysis of 24,179 cases from a prospective nationwide surveillance study. Clin Infect Dis 39, 309-317 (2004).

5. Montagna, M. T. et al. Epidemiology of invasive fungal infections in the intensive care unit: results of a multicenter Italian survey (AURORA Project). Infection 41, 645-653 (2013).

6. Tang, H. J., Liu, W. L., Lin, H. L. \& Lai, C. C. Epidemiology and prognostic factors of candidemia in cancer patients. PLoS One 9, e99103 (2014).

7. Pfaller, M. A. et al. Epidemiology and Outcomes of Invasive Candidiasis Due to Non-albicans Species of Candida in 2,496 Patients: Data from the Prospective Antifungal Therapy (PATH) Registry 2004-2008. PLoS One 9, e101510 (2014).

8. Tzar, M. N. \& Shamim, A. S. Candidaemia and antifungal susceptibility testing in a teaching hospital. Med J Malaysia 64, 61-64 (2009).

9. Pfaller, M. A. \& Diekema, D. J. Epidemiology of invasive candidiasis: a persistent public health problem. Clin Microbiol Rev 20, 133-163 (2007).

10. Aubron, C. et al. The epidemiology of bacteriuria and candiduria in critically ill patients. Epidemiol Infect 143, 653-662 (2014).

11. World Health Organization. Antimicrobial resistance: global report on surveillance. (2014). Available at: http://www.who.int/drugresistance/documents/ surveillancereport/en/. (Accessed on 01/12/2014).

12. Pfaller, M. A. Antifungal drug resistance: mechanisms, epidemiology, and consequences for treatment. Am J Med 125, S3-13 (2012).

13. Hancock, R. E. W. \& Chapple, D. S. Peptide Antibiotics. Antimicrobial Agents and Chemotherapy 43, 1317-1323 (1999).

14. Hancock, R. E. \& Sahl, H. G. Antimicrobial and host-defense peptides as new antiinfective therapeutic strategies. Nat Biotechnol 24, 1551-1557 (2006)

15. Reddy, K. V. R., Yedery, R. D. \& Aranha, C. Antimicrobial peptides: premises and promises. International Journal of Antimicrobial Agents 24, 536-547 (2004).

16. Jenssen, H., Hamill, P. \& Hancock, R. E. W. Peptide Antimicrobial Agents. Clinical Microbiology Reviews 19, 491-511 (2006).

17. Fjell, C. D., Hiss, J. A., Hancock, R. E. W. \& Schneider, G. Designing antimicrobial peptides: form follows function. Nat Rev Drug Discov 11, 37-51 (2012).

18. Podorieszach, A. P. \& Huttunen-Hennelly, H. E. K. The effects of tryptophan and hydrophobicity on the structure and bioactivity of novel indolicidin derivatives with promising pharmaceutical potential. Organic \& Biomolecular Chemistry 8, 1679-1687 (2010).

19. Wang, Y. et al. Design of novel analogues of short antimicrobial peptide anoplin with improved antimicrobial activity. Journal of Peptide Science 20, 945-951 (2014).

20. Thankappan, B. et al. Antimicrobial and antibiofilm activity of designed and synthesized antimicrobial peptide, KABT-AMP. Appl Biochem Biotechnol 170, 1184-1193 (2013)

21. Chia, B. C., Carver, J. A., Mulhern, T. D. \& Bowie, J. H. The solution structure of uperin 3.6, an antibiotic peptide from the granular dorsal glands of the Australian toadlet, Uperoleia mjobergii. J Pept Res 54, 137-145 (1999).

22. Douglas, L. J. Candida biofilms and their role in infection. Trends Microbiol 11, 30-36 (2003).
23. Matsuzaki, K. Control of cell selectivity of antimicrobial peptides. Biochimica et Biophysica Acta (BBA) - Biomembranes 1788, 1687-1692 (2009).

24. Matejuk, A. et al. Peptide-based Antifungal Therapies against Emerging Infections. Drugs Future 35, 197 (2010).

25. Asthana, N., Yadav, S. P. \& Ghosh, J. K. Dissection of antibacterial and toxic activity of melittin: a leucine zipper motif plays a crucial role in determining its hemolytic activity but not antibacterial activity. J Biol Chem 279, 55042-55050 (2004).

26. Justo, J. A. \& Bosso, J. A. Adverse Reactions Associated with Systemic Polymyxin Therapy. Pharmacotherapy: The Journal of Human Pharmacology and Drug Therapy 35, 28-33 (2015)

27. Kim, H., Jang, J. H., Kim, S. C. \& Cho, J. H. De novo generation of short antimicrobial peptides with enhanced stability and cell specificity. Journal of Antimicrobial Chemotherapy 69, 121-132 (2014).

28. Wieprecht, T. et al. Peptide hydrophobicity controls the activity and selectivity of magainin 2 amide in interaction with membranes. Biochemistry 36, 6124-6132 (1997).

29. Chen, Y. et al. Role of peptide hydrophobicity in the mechanism of action of alpha-helical antimicrobial peptides. Antimicrob Agents Chemother 51, 1398-1406 (2007).

30. Chan, D. I., Prenner, E. J. \& Vogel, H. J. Tryptophan- and arginine-rich antimicrobial peptides: Structures and mechanisms of action. Biochimica et Biophysica Acta (BBA) - Biomembranes 1758, 1184-1202 (2006).

31. Wang, Y. et al. Design of novel analogues of short antimicrobial peptide anoplin with improved antimicrobial activity. J Pept Sci 20, 945-951 (2014).

32. Van der Weerden, N. L., Bleackley, M. R. \& Anderson, M. A. Properties and mechanisms of action of naturally occurring antifungal peptides. Cell Mol Life Sci 70, 3545-3570 (2013)

33. Matsuzaki, K. et al. Modulation of magainin 2-lipid bilayer interactions by peptide charge. Biochemistry 36, 2104-2111 (1997).

34. Ramage, G., Saville, S. P., Thomas, D. P. \& Lopez-Ribot, J. L. Candida biofilms: an update. Eukaryot Cell 4, 633-638 (2005)

35. Mukherjee, P. K. \& Chandra, J. Candida biofilm resistance. Drug Resistance Updates 7, 301-309 (2004).

36. Tobudic, S., Kratzer, C., Lassnigg, A. \& Presterl, E. Antifungal susceptibility of Candida albicans in biofilms. Mycoses 55, 199-204 (2012).

37. Burrows, L. L. et al. Activity of novel non-amphipathic cationic antimicrobial peptides against Candida species. J Antimicrob Chemother 57, 899-907 (2006).

38. Harris, M. R. \& Coote, P. J. Combination of caspofungin or anidulafungin with antimicrobial peptides results in potent synergistic killing of Candida albicans and Candida glabrata in vitro. Int J Antimicrob Agents 35, 347-356 (2010).

39. Wei, G.-X. \& Bobek, L. A. In vitro synergic antifungal effect of MUC7 12-mer with histatin-5 12-mer or miconazole. Journal of Antimicrobial Chemotherapy 53, 750-758 (2004)

40. Tavanti, A. et al. Fungicidal activity of the human peptide hepcidin 20 alone or in combination with other antifungals against Candida glabrata isolates. Peptides 32, 2484-2487 (2011).

41. Guilhelmelli, F. et al. Antimicrobial development challenges: the various mechanisms of action of antimicrobial peptides and of bacterial resistance. Frontiers in Microbiology 4, 1-12 (2013).

42. Hawrani, A., Howe, R. A., Walsh, T. R. \& Dempsey, C. E. Origin of low mammalian cell toxicity in a class of highly active antimicrobial amphipathic helical peptides. J Biol Chem 283, 18636-18645 (2008).

43. Jin, Y., Yip, H. K., Samaranayake, Y. H., Yau, J. Y. \& Samaranayake, L. P. Biofilmforming ability of Candida albicans is unlikely to contribute to high levels of oral yeast carriage in cases of human immunodeficiency virus infection. J Clin Microbiol 41, 2961-2967 (2003).

44. Jin, Y., Samaranayake, L. P., Samaranayake, Y. \& Yip, H. K. Biofilm formation of Candida albicans is variably affected by saliva and dietary sugars. Arch Oral Biol 49, 789-798 (2004)

45. Hall, M. J., Middleton, R. F. \& Westmacott, D. The fractional inhibitory concentration (FIC) index as a measure of synergy. J Antimicrob Chemother 11, 427-433 (1983)

46. Kaur, H., Garg, A. \& Raghava, G. P. PEPstr: a de novo method for tertiary structure prediction of small bioactive peptides. Protein Pept Lett 14, 626-631 (2007).

47. Momany, F. A. \& Rone, R. Validation of the general purpose QUANTA ${ }^{\circledR 3}$ 3.2/ CHARMm ${ }^{\circledR}$ force field. Journal of Computational Chemistry 13, 888-900 (1992).

48. Trott, O. \& Olson, A. J. AutoDock Vina: improving the speed and accuracy of docking with a new scoring function, efficient optimization, and multithreading. J Comput Chem 31, 455-461 (2010).

\section{Acknowledgments}

This study was supported by High Impact Research grant (reference number: UM.C/HIR/ MOHE/MED/40, account number H-20001-E000079).

\section{Author contributions}

L.K.Y., S.D.S. and L.C.F. designed experiments. S.D.S. and H.H. funded project. T.S.T., L.K. Y. and R.D.V. performed analysis. L.K.Y. and S.D.S. wrote manuscript. V.S.L. and N.H.S performed docking of peptides. 


\section{Additional information}

Supplementary information accompanies this paper at http://www.nature.com/ scientificreports

Competing financial interests: The authors declare no competing financial interests. How to cite this article: Lum, K.Y. et al. Activity of Novel Synthetic Peptides against Candida albicans. Sci. Rep. 5, 9657; DOI:10.1038/srep09657 (2015).

This work is licensed under a Creative Commons Attribution 4.0 International License. The images or other third party material in this article are included in the article's Creative Commons license, unless indicated otherwise in the credit line; if the material is not included under the Creative Commons license, users will need to obtain permission from the license holder in order to reproduce the material. To view a copy of this license, visit http://creativecommons.org/licenses/by/4.0/ 